\title{
Results of A Thousand Pap Smears Analyzed at the Histology - Embryology and Cell Pathology Laboratory
}

\author{
MOUMOUNI Hassane ${ }^{1}$, HAMA AGHALI Nouhou ${ }^{* 2}$, HAMANI Issaka ${ }^{1}$, OUSMANE Abdoulaye ${ }^{2}$, EFARED Boubacar ${ }^{3}$, \\ HAMADOU Ibrahim ${ }^{1}$, ISSA OUMAROU Boubacar Sidikou ${ }^{1}$, MAMOUDOU Garba ${ }^{4}$, KIMSO Oumou ${ }^{5}$, YADJI DOGO \\ Leila $^{1}$, MOUNKEILA SEYBOU Ibrahim ${ }^{6}$, BOUREIMA Hassane ${ }^{2}$, NOUHOU Hassane ${ }^{3}$ \\ ${ }^{1}$ Laboratory of Histology Embryology and Cellular Pathology / Abdou Moumouni University, Faculty of Health Sciences, Niamey, Niger
}

${ }^{2}$ Laboratory of Reference Hospital / Dan Dicko Dankoulodo University, Faculty of Health Sciences, Maradi, Niger

${ }^{3}$ Laboratory of Cytology and Histopathology / Faculty of Health Sciences of Abdou Moumouni University, Niamey, Niger

${ }^{4}$ Gynecology and Obstetrics Department / Regional Hospital Center of Poudrière, Niamey, Niger

${ }^{5}$ Oncology Department / Reference Hospital, Maradi, Niger

${ }^{6}$ Surgery Department / Reference Hospital, Maradi, Niger

Abstract

Introduction: A Cervical Pap Smear (CPS) is a test that allows early detection of cell lesions. Cervical cancer, the second leading cause of death in women in Africa, manifests itself in precancerous lesions that can be identified by cytology. Methodology: This was a prospective and retrospective study performed over period of 23 years. We examined 1,000 consecutive CPS samples. Results: Over 7658 lab exams done at the laboratory, the frequency CPS was $13,05 \%$. In $43.60 \%$ of cases, the reason for carrying out the examination was systematic screening. The mean age of the patients was 40.93 years. Patients with an age between 37 and 46 years were predominant (34.3\%). This same age group showed more cellular abnormalities with Atypical Squamous Cells of Undetermined Significance (ASCUS) in first position, followed by the low-grade cervical intraepithelial neoplasia (CIN). Infection was found in the 37 and 46 age group and inflammation was present in $29.69 \%$ of cases. The correlation study of age and infection showed a significant link between these two variables ( $p$-value $=0.00000383$ ). Bacterial cervicitis was the cause of infection in 7.8\%, followed by HPV infection 7.2\%. Suspicious epithelial abnormalities were present in $20.87 \%$. High-grade intraepithelial lesions were represented in $1.75 \%$ of cases. The CPS with hemorrhagic characteristics represented $35.80 \%$. At the end of all this we can say that the need to implement policies of systematic surveillance of genital diseases through routine screening at its initial stage is imperative.

KEYWORDS: Cytology, cervical pap smears, Niger.

\section{ABBREVIATIONS}

CPS: cervical pap smears; HE / PCL: Histology Embryology and Cellular Pathology Laboratory; FHS: faculty of health sciences; AMU: Abdou

\section{Vol No: 05, Issue: 01}

Received Date: September 17, 2021

Published Date: October 26, 2021

*Corresponding Author

\section{Dr HAMA AGHALI Nouhou}

Laboratory of Reference Hospital / Dan Dicko

Dankoulodo University, Faculty of Health

Sciences, Maradi, Niger.

WhatsApp: +22795949067

Tel: +22790282142.

E-mail: nhamaaghali@gmail.com

Citation: Hassane M, et al. (2021). Results of A Thousand Pap Smears Analyzed at the Histology - Embryology and Cell Pathology Laboratory. Mathews J Cytol Histol. 5(1):17.

Copyright: Nouhou HA, et al. (C) (2021). This is an open-access article distributed under the terms of the Creative Commons Attribution License, which permits unrestricted use, distribution, and reproduction in any medium, provided the original author and source are credited. 
Moumouni University; ASCUS: Atypical Squamous Cells of Undetermined Significance; CIN: Cervical intraepithelial neoplasia; HPV: Human Papilloma Virus; NS: Non Specified;

\section{INTRODUCTION}

Cytology is the study of the morphological characteristics of human cells, smeared, fixed, and stained on slides. These cells come from different organs or morphological lesions and are obtained either from products of spontaneous cellular sheddingor by superficial scraping of an organ or lesion, and finally by aspiration with a probe or a fine needle [1]. The goal of cervical cytology is the detection of pre-invasive lesions of the cervix and prevention of invasive cancer $[2,3]$. There is no doubt of the effectiveness of cervical cancer screening, and it is because screening helps to detect and treat precancerous conditions [4,5]. Unfortunately, cervical cancer is a public health issue due to its increase on a global scale with an incidence of 570000 new cases/ year [6]. It is the fourth leading cause of e death among women worldwide, with developing countries paying a heavy toll [6,7]. In Africa, this cancer ranks second among gynecologic cancers with a mean incidence of approximately 33.7 cases / 100000 [6]. In Niger, to our knowledge, no study has been carried out on the CPS to this date. The purpose of this study was to analyze results of 1000 CPS examined at the Histology -Embryology and Cellular Pathology laboratory
[HE / CPL] of the Faculty of Health Sciences [FHS] at Abdou Moumouni University of Niamey [AMU].

\section{MATERIALS AND METHOD}

We conducted a retrospective and prospective study from February 28, 1997 to March 23rd, 2020, i.e. over a period of 23 years and one month. Samples were collected at the HE / CPL of the FHS of the AMU of Niamey. A thousand Pap smears were consecutively selected during the study period. Inadequate pap smears were not included. Each smear was stained by the Papanicolaou method. Then, it was examined and analyzed with an optical microscope by the cytologist. The studied variables were age, parity, motif, cellularity, and hemorrhage. Analysis and graphs were done with Microsoft software EXCELL 2016 and R studio. For comparative studies, the chi-square test was used. A threshold of $P$ value $<0.05$ is considered significant

\section{RESULTS}

During the study period, 7658 cytological exams were carried out at the laboratory. i.e. $13.05 \%$ were Cervical Pap Smear.

Age

The patients' age ranged from 17 and 72 years with a mean age of 40.93 years and a median of 41 years. The 37 to 46 age group were the most represented, with $34.30 \%$.

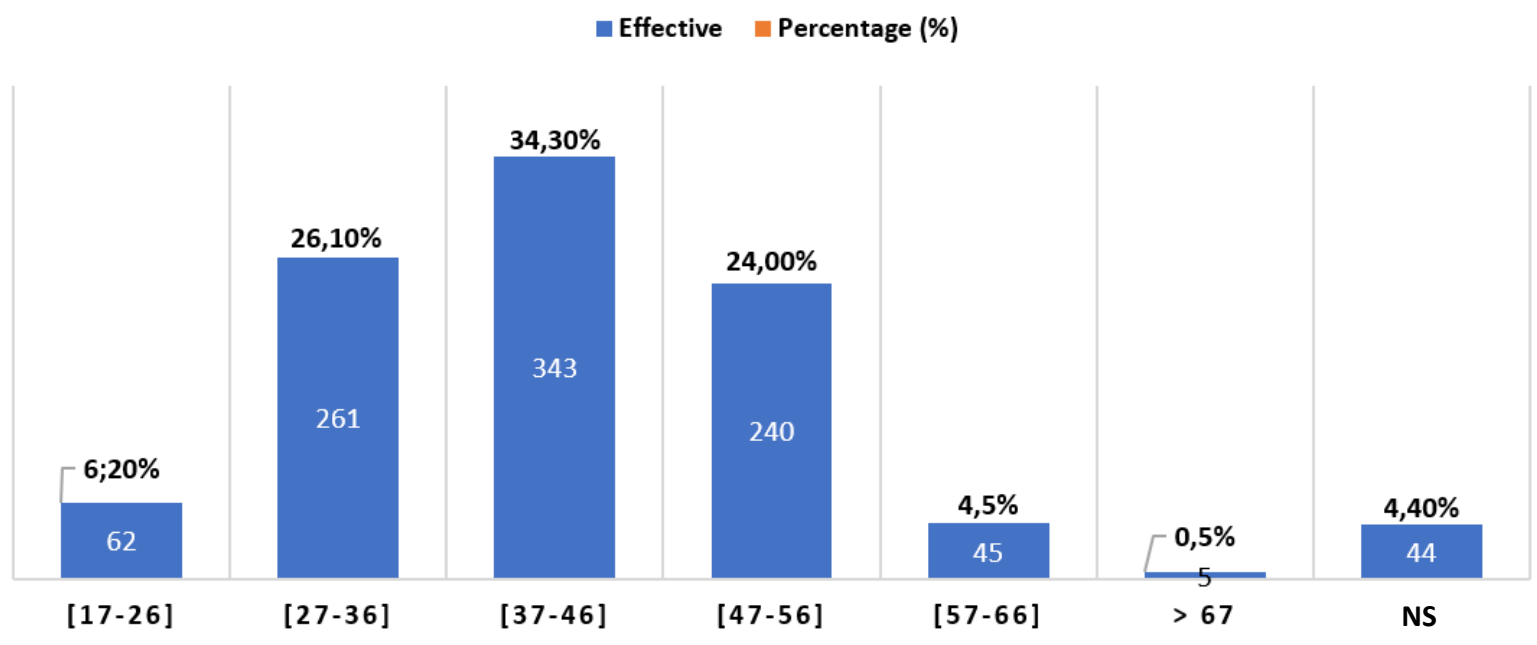

Figure 1: Patients' characteristics according to age.

NS: not specified 


\section{Motif}

Routine screening was the primary indication for CPS with 44, 30\%, followed by those for whom the indication for the Pap smear was not specified, $34 \%$ and in third place vaginal infections $5.10 \%$.

Table 1: Patients' characteristics according to the motif for CPS.

\begin{tabular}{|c|c|c|}
\hline Motif & Effective & Percentage [\%] \\
\hline Spaniomenorrhea & 1 & 0.10 \\
\hline Molar pregnancy & 1 & 0.10 \\
\hline Squamous cell carcinoma & 1 & 0.10 \\
\hline Endometriosis & 1 & 0.10 \\
\hline Discreet hyperkeratosis & 1 & 0.10 \\
\hline Myomatous uterus & 2 & 0.20 \\
\hline Cervical mass & 2 & 0.20 \\
\hline Polyps & 2 & 0.20 \\
\hline Pelvic pain & 2 & 0.20 \\
\hline Cervical mucus & 2 & 0.20 \\
\hline Naboth's cyst & 4 & 0.40 \\
\hline Visual inspection & 5 & 0.50 \\
\hline Strapping & 8 & 0.80 \\
\hline Amenorrhea & 10 & 1.00 \\
\hline Infertility & 10 & 1.00 \\
\hline Modification of the cervix & 19 & 1.90 \\
\hline Ectropion & 24 & 2.40 \\
\hline Chek up & 34 & 3.40 \\
\hline Metrorrhagia & 37 & 3.70 \\
\hline Infection & 51 & 5.10 \\
\hline Unspecified & 340 & 34.00 \\
\hline Routine screening & 443 & 44,30 \\
\hline Total & 1000 & 100 \\
\hline
\end{tabular}

\section{Parity}

Grand multiparous were the most frequent with $7.20 \%$ followed by pauciparous with $6.8 \%$ and multiparous with $5.20 \%$.

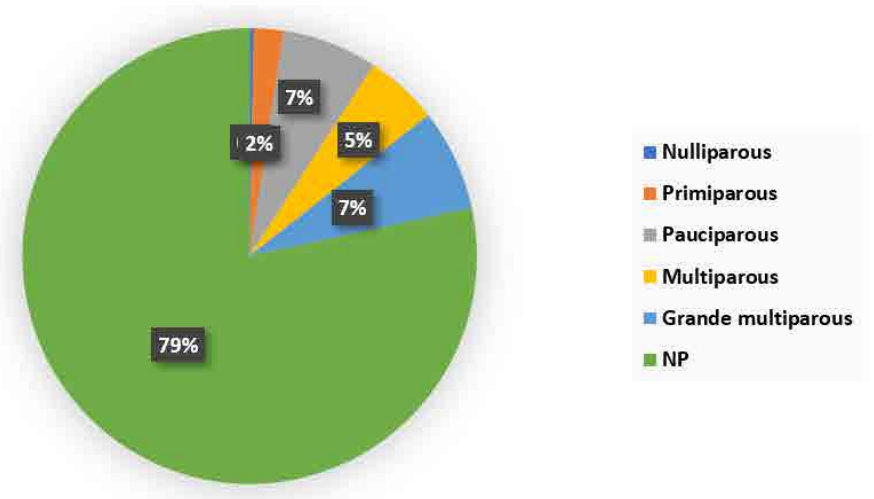

Figure 2: Distribution of patients according to parity.

NP: not specified, Pauciparous [2,3], Multiparous [4,5], Grande multiparous [6,12] 


\section{Cellularity}

The cervical pap smears with fair cellularity were more frequent [50.80\%] followed by those with good cellularity with a rate of $40.60 \%$.

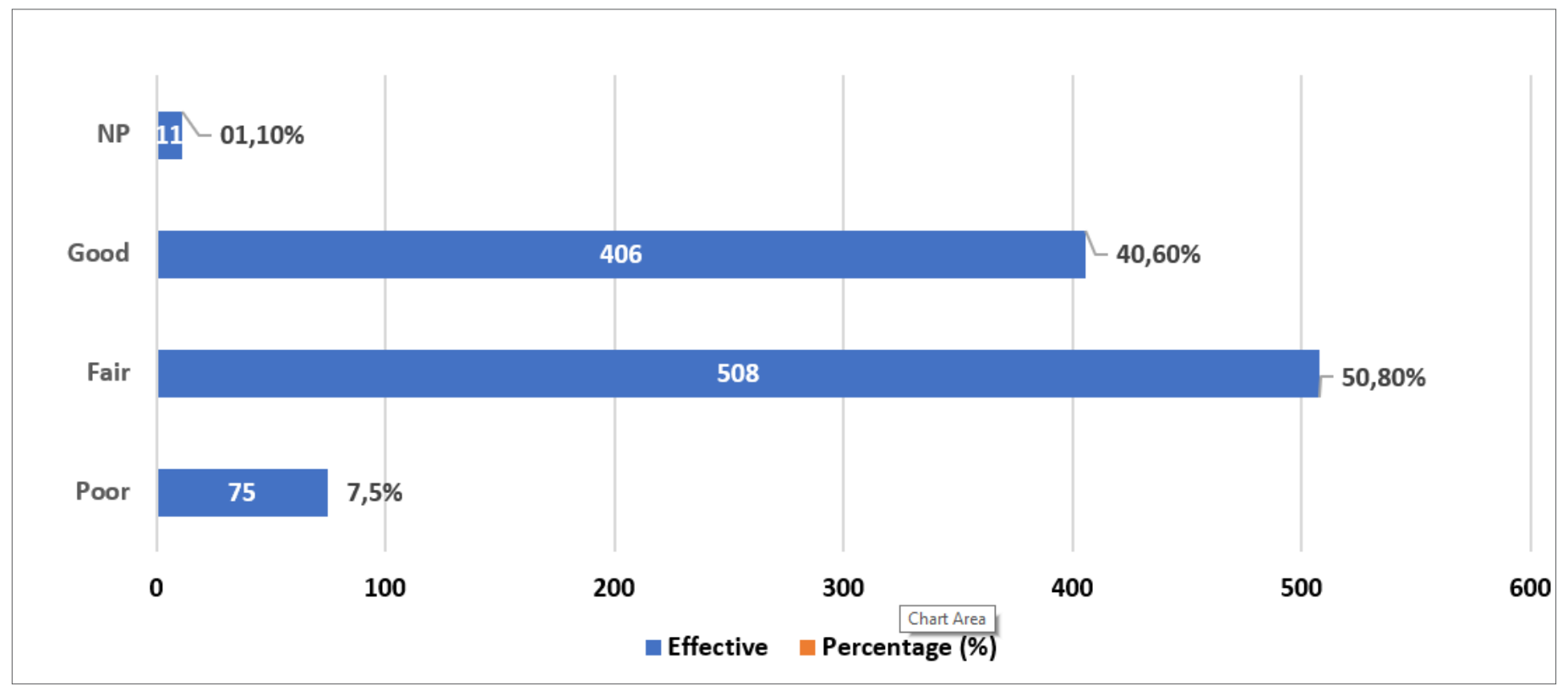

Figure 3: Characteristics of cervical pap smears according to cellularity

\section{Hemorrhagia}

Non- hemorrhagic smears were predominant with $64.20 \%$. The rate of hemorrhagic smear was $35.80 \%$.

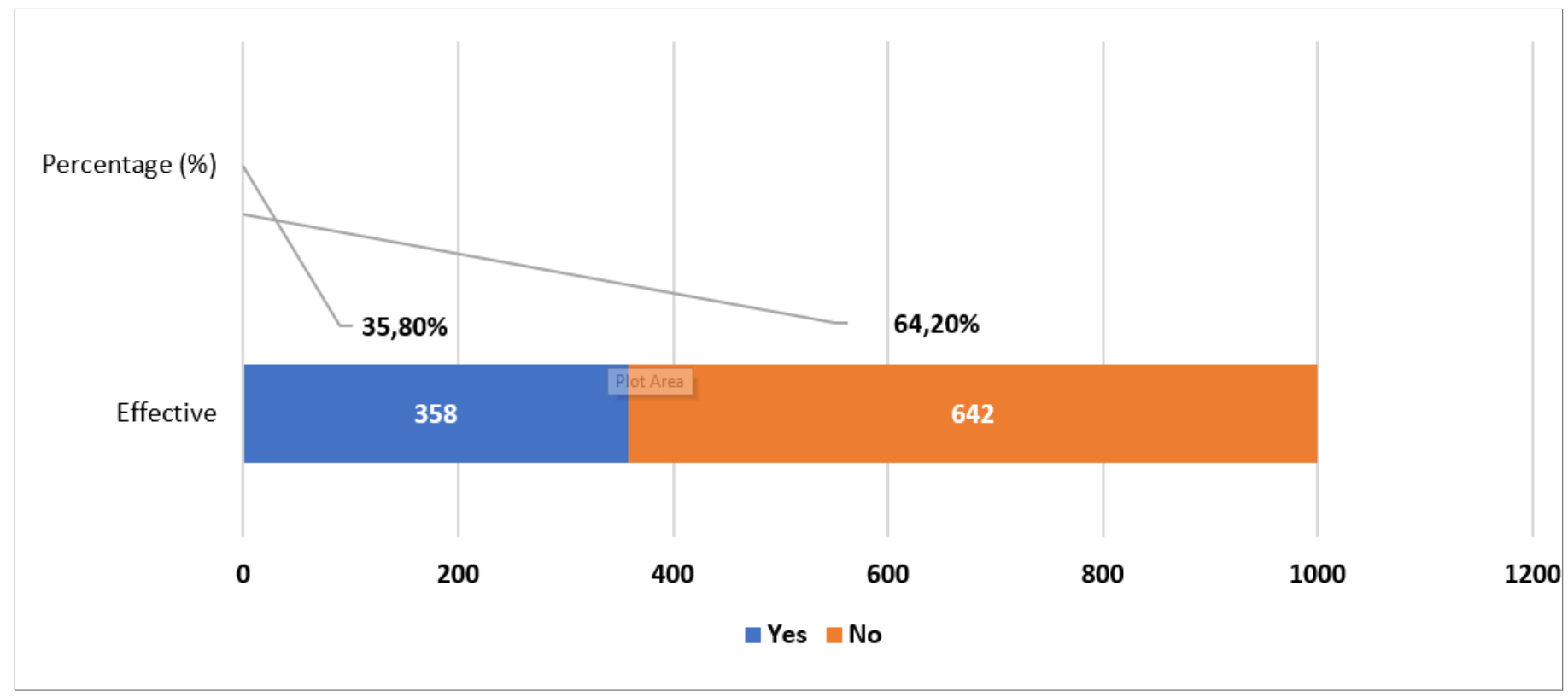

Figure 4: Hemorrhagic aspect of CPS

\section{Distribution of infections according to age}

We noted that the age groups most affected by infections were 37 to 46 years and 27 to 36 years. Bacterial cervicitis infections were more frequent followed by HPV infections. There was a significant correlation between age and infection. [ $P$-value $=0.0000083]$. 
Table 2: Distribution of infections according to age.

\begin{tabular}{lcccc}
\hline & \multicolumn{2}{c}{ Viral infection } & & \\
\cline { 2 - 4 } Age & $\begin{array}{c}\text { HPV } \\
\text { Infection }\end{array}$ & $\begin{array}{c}\text { Herpes } \\
\text { Infection }\end{array}$ & & Fungal cervicitis \\
& & & & \\
\hline $17-26$ & 5 & 1 & 1 & 14 \\
$27-36$ & 22 & 1 & 12 & 27 \\
$37-46$ & 24 & 0 & 6 & 32 \\
$47-56$ & 20 & 0 & 0 & 4 \\
$\geq 57$ & 1 & 0 & 33 & 1 \\
\hline Total & 72 & 2 & & 78 \\
\hline
\end{tabular}

$p$-value $=0.00000383$

\section{Distribution of cell modifications according to age}

Patients between 37 and 46, and 27 and 36 years of age had more cellular changes, of which ASCUS (Atypical Squamous
Cells of Undetermined Significance) were more frequent followed by CIN (Cervical intraepithelial neoplasia) of low grade. There is no statistically significant association between cell changes and age.

Table 3: Distribution of cellular modifications according to age.

\begin{tabular}{|c|c|c|c|c|c|c|c|c|}
\hline $\begin{array}{c}\text { Age } \\
\text { [years] }\end{array}$ & $\begin{array}{l}\text { High grade } \\
\text { CIN }\end{array}$ & $\begin{array}{l}\text { Hyperplasia of } \\
\text { the cylindrical } \\
\text { epithelium }\end{array}$ & $\begin{array}{c}\text { Presence of } \\
\text { viral colpitis }\end{array}$ & $\begin{array}{c}\text { Presence } \\
\text { of suspicious cells which } \\
\text { could not be differentiated }\end{array}$ & $\begin{array}{l}\text { CIN whose grade } \\
\text { could not be } \\
\text { established }\end{array}$ & $\begin{array}{l}\text { Intermediate } \\
\text { grade CIN }\end{array}$ & $\begin{array}{l}\text { Low } \\
\text { grade } \\
\text { CIN }\end{array}$ & ASCUS \\
\hline $17-26$ & 0 & 0 & 1 & 0 & 3 & 0 & 7 & 11 \\
\hline $27-36$ & 4 & 1 & 1 & 1 & 0 & 0 & 29 & 76 \\
\hline $37-46$ & 2 & 0 & 1 & 1 & 4 & 3 & 32 & 83 \\
\hline $47-56$ & 2 & 0 & 0 & 1 & 0 & 0 & 21 & 30 \\
\hline $57-66$ & 0 & 0 & 0 & 1 & 2 & 0 & 1 & 0 \\
\hline$\geq 67$ & 0 & 0 & 0 & 0 & 0 & 0 & 0 & 0 \\
\hline Total & 8 & 1 & 3 & 4 & 9 & 3 & 90 & 200 \\
\hline
\end{tabular}

$p$-value $=0.714$

\section{DISCUSSION}

The most representative age group was that of 37 to 46 years, with $34.30 \%$. The mean age was 40.93 years, with extremes of 17 years and 72 years and a median of 41 years. Our results are similar to those of Bertrand K, Burkina Faso [8] who found that $75.7 \%$ of patients were between the ages of 30 and 49 with an average age of 38 years and extremes of 19 and 92 years old. Gnaoui, et al., in Morocco [6,9] have found that the 41 to 50 years olds were more numerous with $47 \%$ and an average of 50.5 and extremes of 20 years and 81 years. Our results were different from those reported by
Rasoloson LJ in Madagascar [7] where the $\geq 50$ age group was the most represented, with $5.91 \%$ with a mean age of 45.19 years and extremes of 22 and 79 years. This age similarity in most authors can be explained on one hand by the fact that CPS are usually prescribed at this age [10] and secondly by the fact that these patients are frequently exposed to sexually transmitted infections.

Grand Multiparous were more frequent with 7.20 \% followed the pauciparous $6.8 \%$, and multiparous $5.20 \%$. Parity was not specified in $78.40 \%$ of cases. Our results are different from those of Bertrand K. in Burkina Faso [6] who found 
in his study that multiparous were the most represented, i.e. 58.93\% (including pauciparous), followed by grand multiparous with $23.43 \%$. As for Gnaoui, et al., in Morocco [5], they reported that more than half [54\%] of the patients were multiparous. It should be noted that multiparity, the precocity of obstetric trauma to the cervix, their repetition over time and the hormonal disturbances associated with HPV infections are the main mechanisms leading to precancerous and cancerous lesions of the cervix. All of these factors contribute to rapid cellular remodeling at the cervical level, hence the development towards precancerous and cancerous lesions.

The most frequent reason for requesting a pap smear was routine screening, in $43.60 \%$ of cases followed by a vaginal infection, with $5.10 \%$. Those who had metrorrhagia accounted for $3.70 \%$. The motif was not specified in $34 \%$ of cases. Our results are similar to those reported by Nahet, et al., in Algeria [8] who found that the predominant reason for requesting a pap smear was routine screening with $84 \%$. There was a difference between our results and those reported by Ravolamanana, et al., in Madagascar [9], who found that patients with vaginal infection were more frequent with 46.23\%. Rasoloson LJ [7] found in his study that those who had metrorrhagia were more represented, with $59.73 \%$ followed by those who had a genital infection (10.74\%).

In our study, we found that non-hemorrhagic smears were predominant with $64.20 \%$ followed by hemorrhagic smears with a rate of $35.8 \%$. Our results are different from those reported by Bertrand K. in Burkina Faso [6] reported in his study that only $16.95 \%$ were hemorrhagic. Several reasons can explain the presence of blood in the Pap smear; such as an erosion during the exam, a current infection, a malignancy, or the patient was on her menstrual cycle.

There was a statistical significance $p$-value $=0.00000383$ ] between infection and age. In addition, the most concerned patients were relatively young. The age group most affected was those between the ages of 27 to 36 and 37 to 46 with HPV infection followed by bacterial cervicitis. This could be explained by the fact that patients who are relatively young and at childbearing age are often exposed to genital infections [11]. The most commonly infected age is middle age or the age of sexual activity. It has been indicated that anal intercourse may be an idiopathic cause of infection of the genitourinary system in both sexes $[12,13]$. Moreover, sexual activity with more than one partner may be another factor in spreading the infection. This is evidenced by the high prevalence of sexually transmitted diseases among prostitutes and their partners[14].

In our study, analysis of the results by chi-square method showed no Correlation [ $p$-value $=0.0714$ ] between patients' age and the onset of cellular changes. This could be explained by the fact that the occurrence of cellular changes is not influenced by age. However, older women are not excluded from malignant intraepithelial lesions.

\section{CONCLUSION}

It was found that few patients had cellular changes related to intraepithelial neoplasms. However, active surveillance is recommended. Multiparity was most often correlated with the presence of infection and suspicious cell changes. This shows the need to implement policies for systematic surveillance of genital diseases through routine screenings at its initial stage.

\section{REFERENCES}

1. Bakayoko AM. (2015). Bilan des activités de cytologie mammaire et cervico-utérine dans le service d'Anatomie et cytologie pathologiques du CHU du Point G à propos de 486 cas. [Link]

2. Boman F, Duhamel A, Trinh DQ, Farré I, et al. (2004). Correspondance histologique des frottis cervicoutérins détectant un cancer ou une lésion de haut grade. Gynécologie Obstétrique Fertil. 32(5):404-408. [Link]

3. Boulanger J-C, Fauvet R, Urrutiaguer S, Drean Y, et al. (2007). Histoire cytologique des cancers du col utérin diagnostiqués en France en 2006. Gynécologie Obstétrique Fertil. 35(9):764-771. [Link]

4. Goggin P, Mayrand M-H, Groupe de travail sur les lignes directrices pour le dépistage du cancer du col utérin au Québec, Institut national de santé publique du Québec, Direction des risques biologiques et de la santé au travail. (2012). Lignes directrices sur le dépistage du cancer du col utérin au Québec [Internet]. Montréal, Québec: Direction des risques biologiques et de la santé au travail, Institut national de santé publique Québec. [Link]

5. Devulder MD. (1995). La pratique du frottis cervicoutérin avant 25 ans. Gynécologie et obstétrique. p 51. [Link]

6. Belglaiaa E, Mougin C. (2019). Le cancer du col de l'utérus: état des lieux et prévention au Maroc. Bull Cancer [Paris]. 106(11):1008-1022. [Link] 
7. Nahet A, Boublenza L, Hassaine H, Hoceini A, et al. (2015). Étude rétrospective de l'évaluation des activités de dépistage des lésions précancéreuses du col de l'utérus dans une région du sud d'Alger entre 2008 et 2011. J Afr Cancer Afr J Cancer. 7(4):168-172. [Link]

8. Bertrand K. (1997). DEPISTAGE CYTOLOGIQUE DES LESIONS CERVICO UTERINES AU BURKINA FASO: REALITES ACTUELLES. [Faculté des Sciences de la Santé]: Université de Ouagadougou. [Link]

9. Gnaoui NE, Saile R, and Benomar H. (2010). Le frottis cervicovaginal un test incontournable dans le dépistage des lésions du col de l'utérus. J Afr Cancer Afr J Cancer. 2(1):9-13. [Link]

10. Bennis S, Meniar S, Amarti A, and Bijou A. (2007). La place du frottis cervico-vaginal dans le diagnostic du cancer du col utérin au Maroc, région Fès-Boulemane. East Mediterr Health J. 13(5):1153-1159. [Link]
11. AFR-RC67-7 Cadre de mise en œuvre de la Stratégie mondiale sur les IST 2016-2021.pdf [Internet]. [Link]

12. Awad Hegazy A and Hegazy MA. (2019). Anal intercourse and idiopathic infertility: Anatomical considerations and authors' perspective. Trends Med. 19:1-3. [Link]

13. Hegazy DAA. (2016). Mode of Hepatitis C Transmission through Sexual Intercourse: Author Perspective. Acad Anat Int. 2(2):1-2. [Link]

14. Hegazy DA. (2015). Repetitive Anal Intercourse as a Potential Risk for Renal Failure. Acad Anat Int. 1(1):1-2. [Link] 